\title{
Evidence for systemic rather than pulmonary effects of interleukin- 5 administration in asthma
}

\author{
E L J van Rensen, R G Stirling, J Scheerens, K Staples, P J Sterk, P J Barnes, K F Chung
}

\begin{abstract}
Background-Interleukin 5 (IL-5) has an important role in mobilisation of eosinophils from the bone marrow and in their subsequent terminal differentiation. A study was undertaken to determine whether inhaled and intravenous IL-5 could induce pulmonary eosinophilia and bronchial hyperresponsiveness (BHR) independently of these effects.

Methods-Nine mild asthmatics received inhaled $(15 \mu \mathrm{g})$ or intravenous $(2 \mu \mathrm{g}) \mathrm{IL}-5$ or placebo in random order in a double blind, crossover study. Blood samples were taken before and at $0.5,1,2,3,4,5$, 24 , and 72 hours following IL-5 or placebo, and bronchial responsiveness $\left(\mathbf{P C}_{20}\right.$ methacholine) and eosinophil counts in induced sputum were determined.

Results-Serum IL-5 levels were markedly increased 30 minutes after intravenous IL-5 $(p=0.002)$, and sputum IL-5 levels increased 4 and 24 hours after inhaled IL-5 $(p<0.05)$. Serum eotaxin was raised 24 hours after intravenous IL-5 but not after inhaled IL-5 or placebo. Blood eosinophils were markedly reduced $0.5-2$ hours after intravenous IL-5 $(p<0.05)$, followed by an increase at $3,4,5$, and 72 hours $(\mathbf{p}<0.05)$. Sputum eosinophils rose significantly in all three groups at 24 hours but there were no differences between the groups. Bronchial responsiveness was not affected by IL-5.

Conclusion-The effects of IL-5 appear to be mainly in the circulation, inducing peripheral mobilisation of eosinophils to the circulation without any effect on eosinophil mobilisation in the lungs or on bronchial responsiveness.

(Thorax 2001;56:935-940)
\end{abstract}

Keywords: asthma; eosinophil; interleukin 5; bronchial responsiveness

Chronic asthma is characterised by an inflammation of the bronchi with the presence of eosinophils and CD4+ T helper cells. ${ }^{12} \mathrm{~T}$ helper type 2 (Th2) cells are the predominant source of the cytokine interleukin (IL) -5 and are increased in the asthmatic airways. ${ }^{2}$ IL- 5 plays an important role in the mobilisation of eosinophils from the bone marrow and in the terminal differentiation and maintenance of mature eosinophils. ${ }^{3}$ IL-5 levels have been measured in the circulation of asthmatics patients ${ }^{4}$ and rises during asthma exacerbations. ${ }^{1}$ Additionally, increased IL-5 mRNA expression is seen in bronchial mucosa and bronchoalveolar lavage (BAL) CD4+ $\mathrm{T}$ cells in asthma, ${ }^{25}$ and IL-5 protein levels increase following allergen challenge. ${ }^{6}$ A positive correlation between asthma severity and IL- 5 mRNA levels in bronchial biopsy specimens has also been demonstrated.

In guinea pig and rodent models airway administration of IL-5 induces an increase in airway eosinophils without demonstrable change in bronchial responsiveness. ${ }^{89}$ Airway and blood eosinophilia has also been shown in IL-5 transgenic mice, but without bronchial hyperresponsiveness. ${ }^{10-12}$ IL-5 administration to the airways of asthmatic subjects, however, has been associated with peripheral blood eosinophilia, airway eosinophilia, and bronchial hyperresponsiveness. ${ }^{13} 14$

These conflicting observations suggest a complex cooperative role for IL- 5 in the accumulation of circulating and airway eosinophils and their possible subsequent contribution to bronchial hyperresponsiveness. Since IL-5 also appears to have important effects on the bone marrow, ${ }^{915} 16$ we questioned whether the route of IL-5 production was crucial to its effects on the airways. We hypothesised that IL-5 confined entirely to the lungs and airways would have little systemic effect on eosinophil mobilisation, while IL-5 administered to the circulation might possess this primary effect. Further, we sought to establish whether pulmonary or systemic IL-5 could induce specific pulmonary effects consistent with asthma. We therefore investigated the effects of IL-5 administered intravenously or by inhalation to patients with mild asthma on eosinophil counts in blood and in sputum, and on airway hyperresponsiveness.

\section{Methods}

SUBJECTS

Nine non-smoking atopic patients with mild persistent asthma (five women, age range 25-41 years) participated in the study (table 1). All subjects had a history of episodic chest tightness, and wheezing and symptoms were controlled by on demand usage of short acting inhaled $\beta_{2}$ agonists alone. All subjects had been free of symptoms of respiratory tract infection for at least 2 weeks before study commencement. Atopy was determined by positive skin prick responses ( $>3 \mathrm{~mm}$ ) to extracts of six common aeroallergens (Vivodiagnost, ALK, Benelux). Baseline forced expiratory volume in 1 second $\left(\mathrm{FEV}_{1}\right)$ was $>70 \%$ of predicted ${ }^{17}$ and bronchial hyperresponsiveness $\left(\mathrm{PC}_{20}<8 \mathrm{mg} / \mathrm{ml}\right.$ methacholine) was determined by a standardised technique. ${ }^{18}$ The protocol was approved by the ethics committee of the Royal Brompton Hospital and all participants gave written informed consent. 
Table 1 Characteristics of study subjects

\begin{tabular}{llllll}
\hline Subject no & Sex & Age (years) & FEV $(\%$ pred) & $P C_{20}(\mathrm{mg} / \mathrm{ml})$ & $\begin{array}{l}\text { Sputum } \\
\text { eosinophils (\%) }\end{array}$ \\
\hline 1 & $\mathrm{M}$ & 35 & 94 & 0.15 & 2.3 \\
2 & $\mathrm{~F}$ & 26 & 85.6 & 0.19 & 0.5 \\
3 & $\mathrm{~F}$ & 26 & 79 & 0.37 & 6.3 \\
4 & $\mathrm{~F}$ & 27 & 95 & 0.42 & 1.1 \\
5 & $\mathrm{~F}$ & 36 & 97 & 1.44 & 1.0 \\
6 & $\mathrm{~F}$ & 25 & 117 & 2.79 & 0.0 \\
7 & $\mathrm{M}$ & 29 & 106 & 3.73 & 5.9 \\
8 & $\mathrm{M}$ & 28 & 97 & 6.68 & 0.5 \\
9 & $\mathrm{M}$ & 41 & 85 & 8.00 & 0.2 \\
& & $30.3(5.6)^{\star}$ & $95.1(3.8)^{\star}$ & $1.15(2.21) \dagger$ & $1.00(0-6.3) \ddagger$ \\
\hline
\end{tabular}

^Mean (SE); †geometric mean; $\ddagger$ median (range).

PROTOCOL

The study was of a placebo controlled, double blind, crossover design and consisted of three periods (fig 1) separated by washout periods of at least 2 weeks. At a screening visit baseline $\mathrm{PC}_{20}$ and sputum induction were performed. In each period the subjects visited the laboratory on three separate days. On day 1 of each period all subjects received an intravenous and an inhaled administration of either IL- 5 or placebo, or both administration routes contained placebo. Blood eosinophils were determined before and $0.5,1,2,3,4,5,24$, and 72 hours after administration. $\mathrm{PC}_{20}$ and sputum induction were performed at 4,24 and 72 hours following each administration.

\section{IL-5 ADMINISTRATION}

Recombinant human IL-5 (Genzyme, Boston, MA) was reconstituted in $0.9 \% \mathrm{NaCl}(2 \mathrm{ml})$ and administered at a dose of $2 \mu \mathrm{g}$ intravenously via a slow infusion in a forearm vein over a period of 5 minutes. This intravenous dose was calculated according to the levels of IL-5 measured in circulating blood of patients with asthma during an exacerbation. ${ }^{1}$ IL-5 $(15 \mu \mathrm{g})$ was inhaled over 5 minutes via a nebuliser (Mecic-aid, Pagham, Sussex, UK) from a mouthpiece using a one way exhaust valve (LC Plus, Pari, Surrey, UK). To ensure complete inhalation of IL-5 the chamber was then refilled with $2 \mathrm{ml} 0.9 \% \mathrm{NaCl}$ and the nebulisation was repeated.

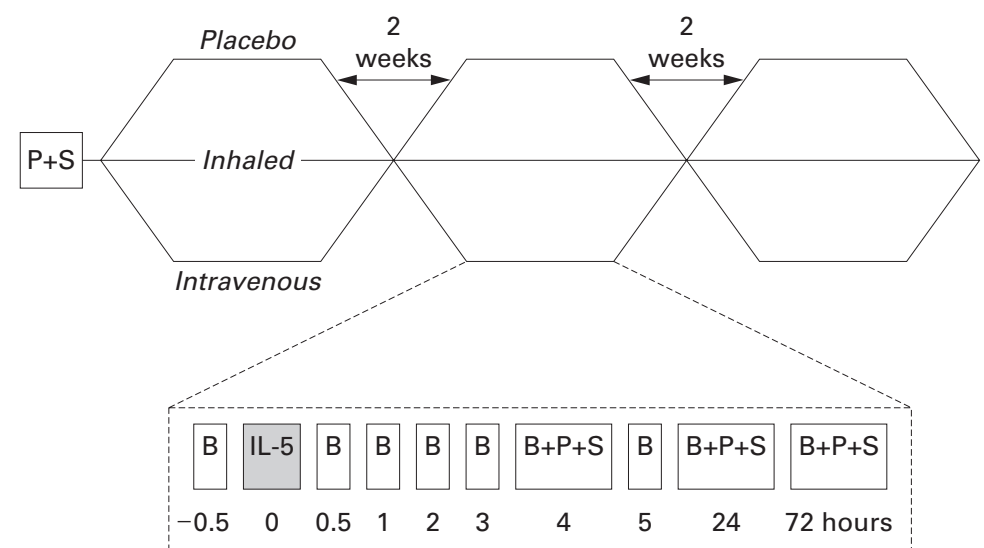

Figure 1 Study design. Subjects were treated in random order with inhaled IL-5 (15 $\mu \mathrm{g})$, intravenous IL-5 (2 $\mu \mathrm{g})$, or placebo in a crossover design at 2 week intervals. Specimen sampling was performed at time points noted. $B=$ blood sample; $P=P C_{20}$ methacholine; $S=$ sputum induction .
LUNG FUNCTION AND METHACHOLINE CHALLENGE Baseline $\mathrm{FEV}_{1}$ was recorded from the best of three attempts using a dry wedge spirometer (Vitalograph, Buckingham, UK). ${ }^{17}$ Spirometric tests were performed prior to and hourly after the administration of IL-5 or placebo until the start of methacholine challenge at 4 hours.

Methacholine challenges were performed according to a standardised methodology. ${ }^{18}$ After a nebulised saline challenge, doubling doses of methacholine $(0.06-32 \mathrm{mg} / \mathrm{ml})$ were administered via a dosimeter (Mefar, Bovezzo, Italy) with an output of $100 \mu$ l. A total of five inhalations of each concentration was administered (inhalation time 1 second, breath holding time 6 seconds). $\mathrm{FEV}_{1}$ was measured 2 and 3 minutes after each dose. The test was discontinued if $\mathrm{FEV}_{1}$ decreased by $20 \%$ or more than with the control inhalation $(0.9 \% \mathrm{NaCl})$. The $\mathrm{PC}_{20}$ was calculated by log-linear interpolation of the last two data points.

PERIPHERAL BLOOD EOSINOPHIL COUNTS

Peripheral blood eosinophils were identified by the combination of peroxidase staining and side scatter and counted using the automated Advia 120 Hematology System (Bayer, Newbury, Berks, UK).

\section{SPUTUM INDUCTION}

All subjects received $200 \mu \mathrm{g}$ salbutamol following the methacholine challenge. After recovery, sputum was induced according to a previously described method. ${ }^{19}$ Hypertonic saline aerosols $(\mathrm{NaCl} 3.5 \%)$ were nebulised at room temperature via an ultrasonic nebuliser (DeVilbiss Ultraneb 2000) at maximum output. Subjects inhaled the aerosols during three 5 minute intervals. Between each interval, or as soon as the subjects started coughing, they were instructed to wash out their mouth and blow their nose in order to minimise salivary contamination. The induced sputum was collected into a $50 \mathrm{ml}$ tube, stored at $4^{\circ} \mathrm{C}$, and processed within 2 hours.

SPUTUM PROCESSING

The whole sputum sample was diluted with $2 \mathrm{ml}$ Hank's balanced salt solution (HBSS) containing $0.25 \%$ dithiotrietol (DTT; Sigma Chemicals, Poole, UK). The sample was gently mixed at room temperature, the volume determined, and the sample further diluted with HBSS to $10 \mathrm{ml}$. The sample was centrifuged (350 g, 10 minutes), supernatant was removed, and the cell pellet was resuspended in $1 \mathrm{ml}$ HBSS. Total cell counts were determined on a haemacytometer slide. Cytospin slides were prepared ( 600 rpm, 6 minutes; Shandon, Runcorn, UK) and stained with May-GrunwaldGiemsa. Differential cell counts were performed by a blinded observer with 300 non-squamous cells counted on each of two slides. To correct for the variable salivary contamination, differential cell counts were expressed as a percentage of 300 nucleated cells, excluding squamous epithelial cells. An adequate sample was defined if there was $<80 \%$ squamous cell contamination. Supernatants were stored at $-80^{\circ} \mathrm{C}$. 
IL-5 AND EOTAXIN ASSAYS

Serum IL-5 and eotaxin and sputum IL-5 levels were measured by ELISA according to the manufacturer's instructions (Pharmingen, Cambridge, UK). Briefly, purified rat antihuman monoclonal antibodies were incubated at $2 \mu \mathrm{g} / \mathrm{ml}$ in coating solution $\left(0.1 \mathrm{M} \mathrm{NaHCO}_{3}\right.$ $(\mathrm{BDH}), \mathrm{pH} 8.2$ at $\left.4^{\circ} \mathrm{C}\right)$ overnight. Plates were washed, then blocked with 10\% FCS for 2 hours at room temperature. Sample supernatants were added to each plate in duplicate. Cytokine standards (R\&D Systems, Abingdon, Oxon, UK) were diluted in $10 \%(\mathrm{v} / \mathrm{v}) \mathrm{FCS} /$ $\mathrm{PBS} /$ Tween and added in duplicate. The plates were then incubated at $4^{\circ} \mathrm{C}$ overnight, biotinylated rat anti-human antibody (R\&D) was added, and they were incubated at room temperature for 45 minutes, then washed before the addition of avidin-peroxidase. The plates were incubated at room temperature for 30 minutes before washing with PBS/Tween and (ABTS, Sigma) substrate. They were then developed for approximately 10 minutes before measurement on a plate reader (Anthos Labtec, Austria) at $405 \mathrm{~nm}$. The detection limit of this assay was $35 \mathrm{pg} / \mathrm{ml}$.

DATA ANALYSIS

$\mathrm{PC}_{20}$ was $\log$ transformed before statistical analysis and reported as geometric mean (SD) values. IL-5 levels and blood and sputum eosinophils were not normally distributed and were therefore $\log$ transformed before analysis and reported as median (range) for eosinophils and geometric mean (SD) for IL-5 levels. Analysis of variance (ANOVA) for repeated measures was used for between group analyses. Within group changes in $\mathrm{PC}_{20}$, sputum and blood eosinophil levels, and serum and sputum supernatant IL-5 were analysed using the Student's paired $t$ test. Mean differences between treatments with $95 \%$ confidence intervals for these effect estimates are presented for serum IL-5 and blood eosinophil counts. All statistical analyses were performed using the SPSS program; $p$ values $<0.05$ were considered statistically significant.

\section{Results}

SERUM AND SPUTUM IL-5 LEVELS

Serum IL-5 levels were rapidly cleared from the circulation and returned to baseline levels between 1 and 72 hours. Serum IL- 5 concentrations in atopic asthmatic patients increased significantly 0.5 hours after intravenous IL- 5 administration (387.4 (162.1) pg/ml) compared with baseline (14.0 (12.8) pg/ml, $\mathrm{p}=0.002)$ with rapid clearance, returning to baseline levels between 1 and 72 hours (fig 2). The serum IL-5 levels at $1,2,3,4$, and 5 hours after intravenous IL-5 were 16.8 (5.9), 14.2 (8.4), 5.7 (3.5), 8.1 (3.9), and $3.7(2.0) \mathrm{pg} / \mathrm{ml}$ respectively, indicating that by 1 hour the levels had returned towards baseline values. In order to determine whether there was any difference in the kinetics of clearance of IL- 5 between asthmatic patients and non-asthmatic controls, we also studied three non-asthmatic non-atopic volunteers. The mean (SE) serum level in non-asthmatic subjects was $3.6(2.5) \mathrm{pg} / \mathrm{ml}$ at baseline, which increased to $54.2(24.6) \mathrm{pg} / \mathrm{ml} 0.5$ hours after intravenous injection of $2 \mu \mathrm{g}$ IL-5 (mean difference $-60.53,95 \% \mathrm{CI}-107.7$ to $-13.3, \mathrm{p}<0.05$; fig 2). These data indicate that there is no difference in the clearance in IL-5 between normal and asthmatic volunteers, although the asthmatic subjects had higher levels of baseline serum IL-5 than non-asthmatics. There was a trend towards an increase in serum IL- 5 levels 0.5 hours after inhaled IL-5 administration (from $18.18(12.4) \mathrm{pg} / \mathrm{ml}$ to $51.14(100.56) \mathrm{pg} /$ $\mathrm{ml}$ ) in the asthmatic subjects, but placebo had no effect on serum IL-5 levels.

There was a significant increase in the IL-5 concentration measured in sputum supernatant from baseline at 4 and 24 hours following inhaled IL-5 (baseline 49.0 (16.4), 4 hours 2067 (1091), 24 hours 152.3 (42.8) pg/ml; $\mathrm{p}=0.04$ and $\mathrm{p}=0.02$, respectively), but no changes in sputum supernatant IL-5 following placebo or intravenous IL-5.

SERUM EOTAXIN

Serum eotaxin levels were $207.5(80.2) \mathrm{ng} / \mathrm{ml}$ at baseline, $248.1(93.6)$ at 0.5 hours, 232.5 (101) at 4 hours, and 301.4 (113.6) at 24 hours following intravenous IL-5. There was a trend to increased serum eotaxin levels following intravenous IL-5 with a 43.0 (23.3)\% increase at 24 hours compared with baseline
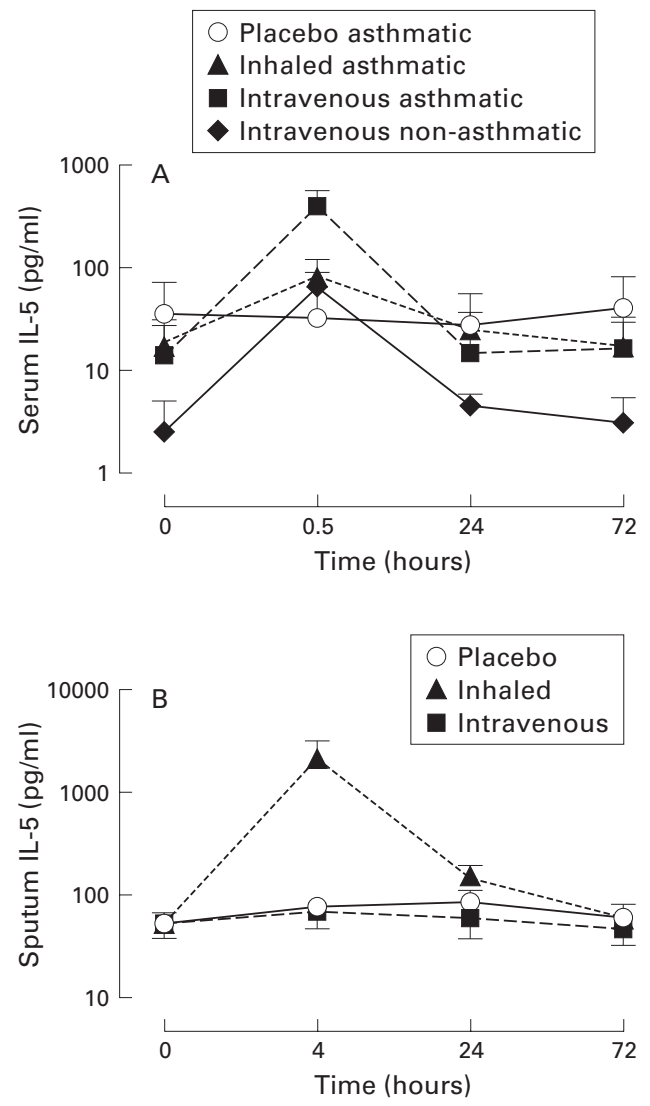

Figure 2 (A) Mean IL-5 serum levels. Serum IL-5 levels rose markedly following intravenous IL-5 but were not significantly increased by inhaled IL-5 or placebo in patients with mild asthma. In addition, in normal volunteers the administration of intravenous IL-5 led to a peak of serum IL-5 levels at 0.5 hours similar to that in patients with asthma. (B) Mean IL-5 levels in sputum supernatants. Sputum IL-5 levels rose 4 hours after inhaled IL-5 and remained raised at 24 hours but were not affected by intravenous IL-5 or placebo. 


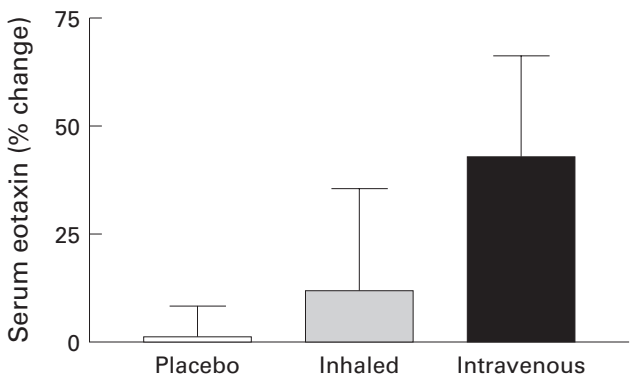

Figure 3 Serum eotaxin. There was a non-significant trend to increased serum eotaxin levels 24 hours after intravenous IL-5 but not after placebo.

(fig 3). Comparative eotaxin levels were 12.0 (23.8) $\mathrm{ng} / \mathrm{ml}$ following inhaled IL-5 and 1.5 (6.8) $\mathrm{ng} / \mathrm{ml}$ following placebo. No correlation was observed between peak IL-5 levels (0.5 hours) and eotaxin levels at 0.5 or 24 hours following IL-5, nor was there correlation between eotaxin levels and peripheral blood lymphocyte or eosinophil numbers.

EFFECT OF IL-5 ON PERIPHERAL BLOOD CELLS Blood eosinophil counts were reduced $30 \mathrm{~min}$ utes (mean difference $0.15,95 \%$ CI 0.05 to $0.26, \mathrm{p}<0.01)$ and 2 hours $(0.13,95 \%$ CI 0.02 to $0.24, \mathrm{p}<0.05)$ following the administration of intravenous IL- 5 compared with baseline (fig 4). The decrease in eosinophils 0.5 hours
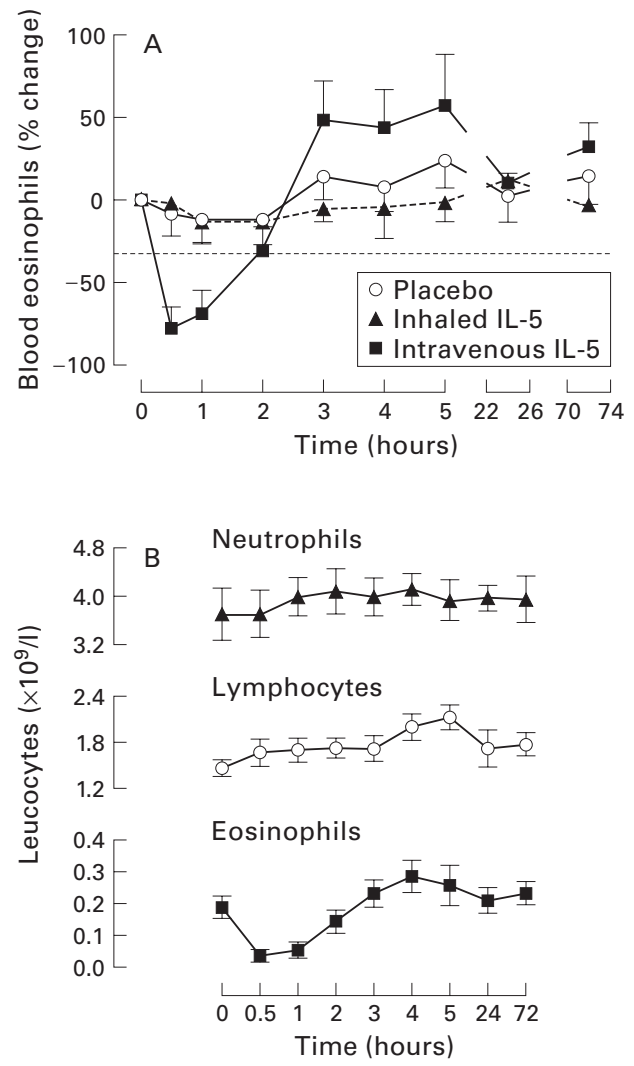

Figure 4 (A) Time course of blood eosinophil counts after placebo, inhaled and intravenous IL-5. Intravenous IL-5 induced a rapid fall in circulating eosinophil numbers $(p<0.05)$ which was not seen with inhaled IL-5 or placebo. There was a prolonged but non-significant increase in eosinophils at 3, 4, 5, and 72 hours after intravenous $I L-5$. (B) Time course of changes in blood neutrophil, lymphocyte, and eosinophil counts after intravenous $I L-5$. Data shown are mean (SE).

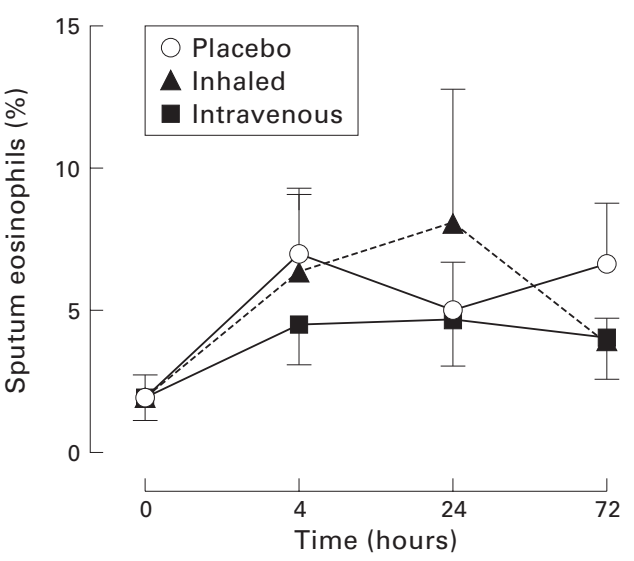

Figure 5 Mean sputum eosinophil counts. Sputum eosinophils were raised 4 hours from baseline in each of the treatment groups but there were no differences between groups at any of the time points measured.

after intravenous administration was significantly different from changes following inhaled IL-5 and placebo $(p<0.03)$. The increase in blood eosinophil counts observed at 3, 4, 5, and 72 hours was not statistically significant.

In addition, peripheral blood lymphocytes were significantly increased from baseline at 4 hours $(\mathrm{p}<0.01$, mean difference $-0.54,95 \% \mathrm{CI}$ -0.97 to -0.11$)$ and 5 hours $(p<0.001,-0.59$, $95 \% \mathrm{CI}-1.02$ to -0.16 ) following intravenous but not inhaled IL- 5 or placebo.

EFFECT OF IL-5 ON SPUTUM EOSINOPHILS

The median sputum eosinophil counts were $1.0 \%$ (range $0-6.3 \%$ ) at baseline, increasing to $5.0 \%$ at 24 hours after inhaled IL-5 $(\mathrm{p}=0.02)$ and persisting at 72 hours $(4.6 \%, \mathrm{p}=0.02)$. However, similar increases were observed after intravenous IL-5 and after placebo treatment (median at 24 hours: $3.6 \%$ and $3.7 \%$, respectively, $\mathrm{p}<0.01$ ). There were no significant differences in sputum eosinophils between the treatment groups (fig 5).

EFFECT OF IL-5 ON LUNG FUNCTION AND BRONCHIAL RESPONSIVENESS

Baseline $\mathrm{FEV}_{1}$ was 95.1 (3.8)\% predicted and $\mathrm{PC}_{20}$ was $1.15(2.21) \mathrm{mg} / \mathrm{ml}$. No significant changes were observed in $\mathrm{FEV}_{1}$ or $\mathrm{PC}_{20}$ during the three study periods (fig 6 ). There were no

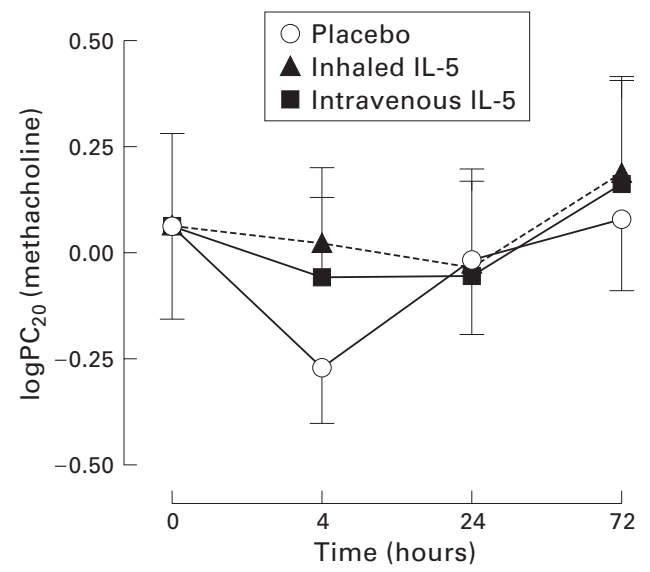

Figure 6 Mean $\log P C_{20}$ to methacholine. Bronchial responsiveness did not change significantly from baseline after inhaled IL-5, intravenous IL-5, or placebo. 
significant correlations between sputum IL-5 levels and change in $\mathrm{PC}_{20}$, nor between eosinophils in blood or sputum and levels of IL-5 measured in sputum or serum.

\section{Discussion}

We report the first observations on the comparative effects of inhaled and intravenous IL-5 in mild asthma. Significant increases were seen in IL-5 levels in the serum but not in the sputum when administered intravenously, and the other way round when given by inhalation. Thus, inhaled IL- 5 appeared to be confined to the lung and intravenous IL-5 to the blood compartment. Intravenous IL-5 induced a rapid decline and subsequent non-significant rise in blood eosinophils which was not associated with airway eosinophilia or bronchial hyperresponsiveness. Sputum eosinophils were indeed slightly increased after intravenous and inhaled IL-5, but were also raised following placebo, which indicates that these increases were non-specific. Inhaled IL-5 had no systemic effect as reflected by blood eosinophil counts or serum eotaxin levels and did not affect bronchial responsiveness. A trend to increased serum eotaxin levels was observed 24 hours following intravenous IL-5. The cellular source of this increase in eotaxin levels could have been the vascular endothelial cells or circulating eosinophil and T cells. Systemic IL-5 is a potent stimulus to eosinophil mobilisation to the circulation, albeit not in itself sufficient specifically to induce lung eosinophilia (as measured in induced sputum) or airway hyperresponsiveness.

We observed significant, sequential, and converse effects on peripheral blood eosinophils following intravenous IL-5. Between 0.5 and 2 hours eosinophils were markedly reduced, and this effect has not been previously reported in animals or humans. At later time points (4-72 hours) there was a significant increase in blood eosinophil counts. We speculate that these effects result from rapid vascular margination followed by either demargination or replenishment of the circulating eosinophil pool from bone marrow and other extramedullary leucocyte reservoirs. A rapidly induced but short lived peripheral eosinophilia has been observed previously following intravenous administration of IL-5 in animals, ${ }^{20}{ }^{21}$ while a prolonged peripheral blood eosinophilia occurred after inhaled IL-5 in asthmatic subjects. ${ }^{13}$

The finding that IL-5 did not specifically affect sputum eosinophils levels contradicts a previous study of IL-5 inhalation in patients with mild asthma. ${ }^{14}$ We observed minor but significant increases in sputum eosinophil numbers in all groups. These changes are unlikely to be explained by methacholine challenge ${ }^{22}$ or repeated sputum induction. ${ }^{23}$ Our findings are, however, consistent with previous studies in rodents. Wang et $a l^{4}$ showed that circulating IL- 5 is essential for the development of airway eosinophilia, whereas local lung IL-5 production did not lead to eosinophil recruitment to the lungs. Similarly, Mould et $a l^{11}$ observed a doubling of eosinophil counts in
BAL fluid following the administration of intrapulmonary and intravenous IL-5 compared with intrapulmonary IL-5 administration alone in mice. Lee and coworkers ${ }^{12}$ created an IL-5 transgenic mouse expressing IL-5 in airway epithelium which developed baseline bronchial hyperresponsiveness and BAL eosinophilia; however, in this model IL-5 was expressed at unusually high levels in the serum with concomitant prominent peripheral eosinophilia.

We saw no effect of IL-5 on bronchial responsiveness. Consistent findings are provided in human studies in which monoclonal anti-IL-5 blocking antibodies substantially reduced allergen induced blood and sputum eosinophilia but had no effect on the late phase response and bronchial hyperresponsiveness to allergen challenge. ${ }^{25}$ These findings have been consistently confirmed in animal models. ${ }^{26}{ }^{27}$ The contribution of IL- 5 to bronchial hyperresponsiveness is contentious and in asthma models it is difficult to dissociate from effects induced by mediators other than IL-5. ${ }^{28-31}$ Consistently, however, IL-5 transgenic mice have prominent airway eosinophilia but have acetylcholine responses similar to wild type mice. $^{32}$ These studies collectively suggest a close association between IL-5 and both circulating and bronchial eosinophil numbers, but a dissociation between pulmonary IL-5 and bronchial responsiveness in both animals and humans. ${ }^{25} 3133$

Our observations are substantially different from those of Shi et $a l^{14}$ in terms of sputum eosinophilia and bronchial responsiveness induced by IL-5, despite using similar amounts of inhaled IL- 5 obtained from a similar source and comparable cohorts of asthmatic patients in terms of severity and baseline sputum eosinophilia. These studies were performed in ethnically different populations, raising the possibility that there may be racial susceptibility to the effects of IL-5. Another possibility is that the high level of endemic parasitic colonisation in China ${ }^{34-36}$ may induce an expanded population of activated tissue eosinophils ${ }^{35-37}$ that are primed to respond more to IL-5. Sputum ECP levels in the mild asthmatics studied by Shi et al were, however, 2-log fold higher than levels previously described in severe asthma. ${ }^{38}$

Collins et $a l^{9}$ reported that, in contrast to intravenous administration, local IL-5 did not induce tissue accumulation of eosinophils. This indicates that local IL-5 has little chemoattractant activity, whereas intravenous IL-5 has a rapid enhancing effect on eosinophil accumulation by stimulating the release of a rapidly mobilisable pool of bone marrow eosinophils. Furthermore, although IL-5 is necessary, other signals from activated $\mathrm{T}$ lymphocytes may also be required to induce accumulation of eosinophils in the airways. $^{203940}$ Eotaxin, an eosinophil selective chemokine, augments the accumulation of eosinophils by IL-5 in a synergistic fashion. This implies that IL-5 and eotaxin act cooperatively to promote the recruitment of eosinophils into the tissue. ${ }^{9}{ }^{20}$ Our data indicate 
that, when administered on its own to the airways by aerosol, IL- 5 is not capable of inducing eosinophilic inflammation and bronchial hyperresponsiveness in mild asthmatic subjects. However, changes in circulating eosinophil numbers were observed with intravenous administration of IL-5, indicating potential systemic effects on the bone marrow. Thus, IL-5 may have systemic rather than pulmonary effects in asthma.

The authors thank GlaxoWellcome for their support of this study.

1 Corrigan CJ, Haczku A, Gemou-Engesaeth V, et al. CD4 T-lymphocyte activation in asthma is accompanied by increased serum concentrations of interleukin-5. Effect of glucocorticoid therapy. Am Rev Respir Dis 1993;147:540-7.

2 Robinson DS, Hamid Q, Ying S, et al. Predominant TH2-like bronchoalveolar T-lymphocyte population in atopic asthma. N Engl f Med 1992;326:298-304.

3 Kotsimbos AT, Hamid Q. IL-5 and IL-5 receptor in asthma. Mem Inst OswaldoCruz 1997;92(Suppl 2):75-91.

4 Alexander AG, Barkans J, Moqbel R, et al. Serum interleukin 5 concentrations in atopic and non-atopic interleukin 5 concentrations in atopic and non-atopic patients with glucocorticoid-dep

5 Humbert M, Ying S, Corrigan C, et al. Bronchial mucosal expression of the genes encoding chemokines RANTES and MCP-3 in symptomatic atopic and nonatopic asthmatics: relationship to the eosinophil-active cytokines interleukin (IL)-5, granulocyte macrophage-colonystimulating factor, and IL-3. Am F Respir Cell Mol Bio 1997;16:1-8

6 Gauvreau GM, Watson RM, O'Byrne PM. Kinetics of allergen-induced airway eosinophilic cytokine production and airway inflammation. Am f Respir Crit Care Med 1999; 160:640-7.

7 Humbert M, Corrigan CJ, Kimmitt P, et al. Relationship between IL-4 and IL-5 mRNA expression and disease severity in atopic asthma. Am f Respir Crit Care Med 1997; 156:704-8.

8 Iwama $\mathrm{T}$, Nagai $\mathrm{H}$, Suda $\mathrm{H}$, et al. Effect of murine recombinant interleukin-5 on the cell population in recombinant interleukin-5 on the cell population

9 Collins PD, Marleau S, Griffiths-Johnson DA, et al. Cooperation between interleukin-5 and the chemokine eotaxin to induce eosinophil accumulation in vivo. $\mathcal{f} \operatorname{Exp}$ Med 1995;182:1169-74.

10 Hisada T, Hellewell PG, Teixeira MM, et al. $\alpha 4$ integrindependent eotaxin induction of bronchial hyperresponsiveness and eosinophil migration in interleukin-5 transgenic mice. Am ₹ Respir Cell Mol Biol 1999;20:992-1000.

11 Mould AW, Ramsay AJ, Matthaei KI, et al. The effect of IL-5 and eotaxin expression in the lung on eosinophil trafficking and degranulation and the induction of bronchial hyperreactivity. F Immunol 2000;164:2142-50.

12 Lee JJ, McGarry MP, Farmer SC, et al. Interleukin-5 expression in the lung epithelium of transgenic mice leads to pulmonary changes pathognomonic of asthma. $\mathcal{F}$ Exp Med 1997;185:2143-56.

$13 \mathrm{Shi} \mathrm{HZ}, \mathrm{Li} \mathrm{CQ}$, Qin SM, et al. Effect of inhaled interleukin-5 on number and activity of eosinophils in cirinterleukin-5 on number and activity of eosinophils in cir-

14 Shi HZ, Xiao CQ, Zhong D, et al. Effect of inhaled interleukin-5 on airway hyperreactivity and eosinophilia in asthmatics. Am 7 Respir Crit Care Med 1998;157:204-9.

15 Denburg JA, Inman MD, Wood LJ, et al. Bone marrow progenitors in allergic airways diseases: studies in canine and human models. Int Arch Allergy Immunol 1997;113:181-3. 6 Denburg JA, Sehmi R, Upham J, et al. Regulation of IL-5 and IL-5 receptor expression in the bone marrow of allergic asthmatics. Int Arch Allergy Immunol 1999;118:101-3.

17 Quanjer PH, Tammeling GJ, Cotes JE, et al. Lung volumes and forced ventilatory flows. Report Working Party Standardization of Lung Function Tests, European Community for Steel and Coal. Official Statement of the European Respiratory Society (see comments). Eur Respir f Suppl 1993;16:5-40.
18 Sterk PJ, Fabbri LM, Quanjer PH, et al. Airway responsiveness. Standardized challenge testing with pharmacological, physical and sensitizing stimuli in adults. Report Working Party Standardization of Lung Function Tests, European Community for Steel and Coal. Official Statement of the European

19 Keatings VM, Jatakanon A, Worsdell YM, et al. Effects of inhaled and oral glucocorticoids on inflammatory indices in asthma and COPD. Am $\mathcal{f}$ Respir Crit Care Med 1997;155:542-8.

20 Mould AW, Matthaei KI, Young IG, et al. Relationship between interleukin-5 and eotaxin in regulating blood and tissue eosinophilia in mice. F Clin Invest 1997;99:1064-71.

21 Portanova JP, Christine LJ, Rangwala SH, et al. Rapid and selective induction of blood eosinophilia in guinea pigs by
recombinant human interleukin 5. Cytokine 1995;7:775-83.

22 Spanevello A, Vignola AM, Bonanno A, et al. Effect of methacholine challenge on cellular composition of sputum induction. Thorax 1999;54:37-9.

23 Nightingale JA, Rogers DF, Barnes PJ. Effect of repeated sputum induction on cell counts in normal volunteers.

24 Wang J, Palmer K, Lotvall J, et al. Circulating, but not local lung, IL-5 is required for the development of antigeninduced airways eosinophilia. F Clin Invest 1998;102:113241.

25 Leckie $M$, ten Brinke A, Khan J, et al. Effects of an interleukin blocking monoclonal antibody on eosinophils, airway hyperresponsiveness, and the late asthmatic response. Lancet 2000;356:2144-8.

26 Nagai H, Yamaguchi S, Inagaki N, et al. Effect of anti-IL-5 monoclonal antibody on allergic bronchial eosinophilia and airway hyperresponsiveness in mice. Life Sci 1993;53: L243-7.

27 Egan RW, Athwal D, Bodmer MW, et al. Effect of Sch 55700 , a humanized monoclonal antibody to human interleukin-5, on eosinophilic responses and bronchial interleukin-5, on eosinophilic responses and bronch
hyperreactivity. Arzneimittelforschung 1999;49:779-90.

28 Nagai H, Yamaguchi S, Tanaka H. The role of interleukin-5 (IL-5) in allergic airway hyperresponsiveness in mice. Ann NY Acad Sci 1996;796:91-6.

29 Hamelmann E, Cieslewicz G, Schwarze J, et al. Antiinterleukin 5 but not anti-IgE prevents airway inflammation and airway hyperresponsiveness. Am f Respir Crit Care Med 1999;160:934-41.

30 Mauser PJ, Pitman AM, Fernandez X, et al. Effects of an antibody to interleukin-5 in a monkey model of asthma. Am $\mathcal{F}$ Respir Crit Care Med 1995;152:467-72.

31 Mathur M, Herrmann K, Li X, et al. TRFK-5 reverses established airway eosinophilia but not established hyperresponsiveness in a murine model of chronic asthma. Am $\mathcal{F}$ Respir Crit Care Med 1999;159:580-7.

32 Iwamoto T, Takatsu K. Evaluation of airway hyperreactivity in interleukin-5 transgenic mice. Int Arch Allergy Immunol 1995;108(Suppl 1):28-30.

33 Nagai H, Yamaguchi S, Maeda Y, et al. Role of mast cells, eosinophils and IL-5 in the development of airway hyperresponsiveness in sensitized mice. Clin Exp Allergy 1996;26:
$642-7$.

34 Yu S, Xu L, Jiang Z, et al. Report on the first nationwide survey of the distribution of human parasites in China. 1 . Regional distribution of parasite species. Chung Kuo Chi Sheng Chung Hsueh Yu Chi Sheng Chung Ping Tsa Chih 1994;12:241-7.

35 Rumbley CA, Sugaya H, Zekavat SA, et al. Activated eosinophils are the major source of Th2-associated cytokines in the schistosome granuloma. f Immunol 1999;162:1003-9.

36 Williams TJ, Griffiths-Johnson DA, Jose PJ, et al. Eosinophil chemoattractants generated in vivo. Agents Actions Suppl 1995;46:1-9.

37 Hall LR, Mehlotra RK, Higgins AW, et al. An essential role for interleukin-5 and eosinophils in helminth-induced airway hyperresponsiveness. Infect Immun 1998;66:4425-30.

38 Louis R, Lau LC, Bron AO, et al. The relationship between airways inflammation and asthma severity. Am F Respir Crit Care Med 2000;161:9-16.

39 Foster PS, Hogan SP, Ramsay AJ, et al. Interleukin 5 deficiency abolishes eosinophilia, airways hyperreactivity, and lung damage in a mouse asthma model. 7 Exp Med 1996;183:195-201.

40 Hogan SP, Foster PS. Cellular and molecular mechanisms involved in the regulation of eosinophil trafficking in vivo Med Res Rev 1996;16:407-32. 